\title{
PENGARUH GAJI, PROMOSI JABATAN, DAN REKAN KERJA TERHADAP KEPUASAN KERJA KARYAWAN PT. BANK RAKYAT INDONESIA (PERSERO) TBK, KANTOR CABANG BIREUEN
}

\author{
Mai Simahatie ${ }^{1 *}$ dan Zainuddin Iba ${ }^{2)}$ \\ 1,2 Dosen FE Universitas Islam Kebangsaan Indonesia \\ *) email: maisimahatie@gmail.com
}

DOI:

https://doi.org/10.55178/idm.v2i3.210

ABSTRACT

Article history

Received:

March 8, 2021

Revised:

March 15, 2021

Accepted:

March 16, 2021

Page:

$12-20$

Kata kunci:

Salary,

job promotion,

co-workers,

employee job

satisfaction

The purpose of this study was to see 1) The effect of salary on job satisfaction of BRI employees in the Bireuen Branch, 2) the effect of promotion on job satisfaction of employees of the BRI Bireuen Branch, 3) The influence of colleagues on job satisfaction of employees of the BRI Bireuen Branch, 4) The effect of salary, promotion position, colleagues on job satisfaction of BRI employees at the Bireuen Branch jointly (simultaneously). This research was conducted at PT Bank Rakyat Indonesia (Persero) Tbk Bireuen Branch Office, having its address at Jl Medan Banda Aceh Simpang 4 Bireuen. As for the variables in this study are salary, promotion, coworkers, and job satisfaction. The population in this study were all employees of BRI Bireuen Branch as many as 182 employees. Determination of the sample using the Slovin formula and the results are 125 people. The research method used is quantitative research. The analysis used is multiple regression analysis with the help of SPSS 17 and shows the results: from three independent variables, namely salary, job promotion and co-workers, it is found that salaries and co-workers partially affect employee job satisfaction with the value of the salary regression coefficient (X1). is 0.288 and co-workers (X3) is 0.451 while Job Promotion (X2) has no effect with the regression coefficient value of 0.63 . Simultaneously, salary, job promotion, coworkers have an effect on job satisfaction of employees of BRI Bireuen Branch, the value of $R$ Squer is 0.754 or $75.4 \%$, the rest is influenced by other factors that are not discussed.

\section{Pendahuluan (Introduction)}

Kepuasan kerja merupakan keadaan emosional yang menyenangkan atau tidak menyenangkan dalam memandang suatu pekerjaan, dimana kepuasan kerja tersebut dapat diindikasi melalui kenyamanan kerja, dukungan rekan kerja, sistem kompensasi yang baik, kesesuaian pekerjaan, kualitas supervisi dan kesempatan promosi jabatan.

Kepuasan kerja akan menciptakan karyawan yang cinta terhadap pekerjaan, dan hal tersebut akan mendorong karyawan untuk berprestasi lebih baik. Prestarsi yang baik akan menimbulkan imbalan ekonomi dan psikologis yang lebih tinggi. Apabila imbalan tersebut dipandang pantas dan adil maka timbul kepuasan pada diri karyawan karena karyawan merasa bahwa mereka menerima imbalan sesuai dengan prestasinya, hal ini sesuai dengan yang disampaikan oleh Robbins (2001: 179) yang menyatakan bahwa kepuasan kerja sebagai suatu sikap umum sesorang individu terhadap pekerjaanya.

Kepuasan kerja yang baik juga akan meningkatkan moral kerja, dedikasi, kecintaan dan kedisiplinan karyawan menjadi meningkat.Sikap kerja merupakan sikap emosional yang menyenangkan dan mencintai pekerjaannya. Sikap ini dicerminkan oleh moral kerja, disiplin dan prestasi kerja (Indra Dan Adam (2000: 115). Oleh karenannya kepuasan kerja sangat penting diperhatikan, karena erat kaitannya dengan kinerja seseorang, Karyawan yang puas dengan apa yang diperolehnya dari perusahaan akan memberikan lebih dari 
apa yang diharapkan sehingga akan meningkatkan kinerja dirinya dan akan berpengaruh pada kinerja perusahaan.

Namun, point penting yang harus diketahui adalah kepuasan kerja karyawan tidak muncul dengan sendirinya, tentu terdapat faktor faktor yang mempengaruhi kepuasan kerja itu muncul seperti gaji yang cukup, rekan kerja yang menyenangkan, pekerjaan yang sesuai dengan keinginan, lingkungan kerja yang nyaman dan promosi jabatan yang diberikan perusahaan dan lain sebagainya.

Gaji merupakan salah satu hal pokok yang harus diperhatikan dan merupakan salah satu faktor yang dapat mempengaruhi kepuasan kerja karyawan. Gaji adalah suatu bentuk pembayaran periodik dari seseorang majikan pada karyawannya yang dinyatakan dalan suatu kontrak kerja yang menjadi motivasi penting yang ikut mendorong karyawan untuk berprestasi, sehingga tinggi rendahnya gaji yang diberikan akan mempengaruh kinerja dan kesetiaaan karyawan.

Disamping itu, factor terkait lainnya adalah promosi jabatan, juga merupakan salah satu faktor dari kepuasan kerja bagi karyawan. Promosi dapat diartikan sebagai suatu proses perubahan dari suatu pekerjaan ke suatu pekerjaan yang lain dalam hierarki wewenang dan tanggung jawab yang lebih tinggi ketimbang dengan wewenang dan tanggung jawab yang telah dibebankan kepada diri tenaga kerja pada waktu sebelumnya. Promosi jabatan juga merupakan pemindahan karyawan dari suatu posisi atau jabatan, ke posisi atau jabatan yang lebih tinggi dengan gaji, fasilitas, tanggung jawab dan peluang lebih besar.

Penelitian Kosteas (2009) menemukan setelah karyawan menerima promosi dari atasannya, dalam dua tahun terakhir dapat menyebabkan meningkatnya kepuasan kerja karyawan. Naveed et al. (2011) juga mengemukakan salah satu faktor penting untuk meningkatkan kepuasan kerja karyawan adalah promosi jabatan. Promosi jabatan yang di lakukan oleh manajemen perusahaan memberikan peranan penting bagi setiap karyawannya, bahkan setiap karyawannya menjadikan promosi jabatan sebagai sebuah impian dan tujuan yang selalu di harapkan oleh karyawan. Promosi jabatan karyawan tidak hanya semata-mata akan memberikan kekuasaan lebih tapi juga bagi setiap karyawan akan merasa status sosialnya meningkat.

Selanjutnya dilihat dari sisi kesempatan promosi jabatan, PT Bank Rakyat Indonesia (persero) Tbk membuka kesempatan kepada seluruh karyawan nya untuk mengikuti job opening dan meniti karir di BRI, namun tentu saja harus megikuti serangkaian test. Bagi karyawan yang mengikuti test tidak dipungut biaya apapun, bahkan akan diberikan uang transportasi dan biaya penginapan selama mengikuti test di Banda Aceh. Hal ini tentu sangat menarik, dan semua karyawan berlomba lomba untuk dapat mengikuti job opening, hal ini tentu juga dapat memberikan kepuasan tersendiri bagi karyawan

Kemudian, faktor rekan kerja juga merupakan faktor berikutnya yang dapat memberikan kepuasan kerja karyawan, dimana menurut Kamus Besar Bahasa Indonesia Suharso dan Retnoningsih (2005:79) rekan kerja adalah orang yang mempunyai hubungan timbal balik dalam satu tempat kerja, rekan kerja adalah kelompok kerja yang saling mendukung dalam mempelajari penyelesaian tugas. Rekan kerja yang baik akan mendorong seseorang untuk bekerja lebih baik dan bersikap positif seperti mempunyai kesetiaan yang lebih tinggi terhadap rekan dan pekerjaan, kegembiraan, serta mempunyai kepuasan dalam bekerja (Moekijat, (2003: 136) .

Berkaitan dengan uraian diatas, maka penelitian ini bertujuan untuk mengetahui, 1) pengaruh gaji terhadap kepuasan kerja karyawan, 2) pengaruh promosi jabatan terhadap kepuasan kerja karyawan, 3) pengaruh rekan kerja terhadap kepuasan kerja karyawan PT Bank Rakyat Indonesia (Persero) Tbk Kantor Cabang Bireuen.

\section{Tinjauan Literatur (Literature Review)}

\section{a. Pengaruh Gaji Terhadap Kepuasan Kerja Karyawan}

Rivai (2005:379) dalam Kadarisman (2012:316) menyampaikan gaji adalah balas jasa dalam bentuk uang yang diterima karyawan sebagai konsekuensi dari statusnya sebagai pegawai yang memberikan konstribusi dalam mencapai tujuan perusahaan

Heneman dan Schwab (dalam Rita Andini, 2006) membagi aspek kepuasan gaji terdiri dari empat subdimensi: tingkat gaji, (pay level), Kompensasi (benefit), kenaikan gaji (pay raise) strktur atau pengelolaan gaji (pay structure and administration). Dengan indikator sebagai berikut:

a. Tingkat Gaji (pay level) yaitu seberapa besar keadilan dalam penerimaan upah karyawan

b. Kompensasi (benefit) yaitu seberapa keuntungan atau manfaat diterima oleh karyawan

c. Kenaikan Gaji (pay raise) yaitu seberapa besar kenaikan upah yang sesuai dengan kebutuhan 
d. Struktur dan administrasi penggajian (pay struckture and adminsitration) yaitu: bagaimana memberikan nilai besar kecilnya upah atau gaji berdasarkan tingkat atau kedudukannya dalan suatu perusahaan.

Alan J.Dubunsky, Masaaki Kotabe dan Chae Un Lim dalam Farida (2001), menemukan bahwa aturan main pembayaran kompensasi, tinggi rendahnya tingkat kompensasi dan kebijakan atas jabatan tertentu berkorelasi positif terhadap kepuasan kerja. Gaji merupakan bagian dari kompensasi yang diterima karyawan yang digunakan perusahaan untuk memotivasi karyawan untuk semangat bekerja dan diharapkan memberikan kepuasan tersendiri bagi karyawan, karena karyawan akan termotivasi dan merasa puas jika gaji diberikan secara adil. Hal ini sesuai dengan yang disampaikan Lum Et al (Suwandi dan Indriantor, 2009) bahwa kepuasan gaji diartikan bahwa seseorang akan terpuaskan dengan gajinya ketika persepsi terhadap gaji dan apa yang mereka peroleh sesuai dengan yang diharapkan.

Dari pemaparan diatas dapat disimpulkan bahwa gaji berpengaruh positif terhadap kepuasan kerja karyawan.

\section{b. Pengaruh Promosi Terhadap Kepuasan Kerja Karyawan}

Menurut Samsudin (dalam Kadarisman, 2012: 126-127) promosi berarti perpindahan dari suatu jabatan ke jabatan yang lain yang mempunyai status dan tanggung jawab yang lebih tinggi. Hal ini berarti bahwa kompensasi (penerimaan upah/gaji dan sebagainya) menjadi lebih tinggi dibanding dengan jabatan lama.

Sastrohadiwiryo (2005) dalam Ayu (2015:23), mengemukakan "dimensi dan indikator promosi jabatan yakni :"

a. Peningkatan tanggung jawab pekerjaan.

Indikatornya antara lain penilaian pelaksanaan pekerjaan, Peningkatan konsistensi pekerjaan, kemungkinan pengembangan,dan keahlian yang lebih.

b. Pengembangan peningkatan tugas.

Indikatornya Antara lain Pengalaman dan pengetahuan yang memadai, status pendidikan,dan dapat dipercaya.

Promosi jabatan yang dilakukan oleh manajemen perusahaan memiliki peranan penting bagi setiap karyawannya, bahkan setiap karyawan menjadikan promosi jabatan sebagai sebuah impian dan tujuan yang selalu diharapkan oleh karyawna. Dengan adanya promosi jabatan diharapkan dapat meningkatkan sikap karyawan terhadap pekerjaannya dan membangun kepuasan kerja yang tinggi.

Promosi jabatan adalah bentuk penghargaan yang diharapkan oleh karyawan atas prestasi kerja yang dicapai. Dengan adanya promosi berdasarkan penilaian secara objektif, karyawan akan terdorong untuk lebih giat dan lebih disiplin dalam bekerja sehingga menghasilkan kinerja yang baik.

Promosi jabatan bertujuan meningkatkan sikap peduli karyawan terhadap pekerjaannya dan membangun kepuasan kerja yang tinggi. Hal ini sesuai dengan yang disampaikan oleh Malayu SP. Hasibuan pada Buku Sumber Daya Masusia hal. 113, bahwa Promosi jabatan memiliki banyak tunjuan, dan salah satu tujuan dari promosi jabatan tersebut adalah dapat menciptakan kepuasan dan kebanggaan pribadi, status sosial yang semakin tinggi dan penghasilan yang lebih besar bagi karyawan. Dari pemaparan diatas terlihat bahwa promosi jabatan berpengaruh posifit terhadap kepuasan kerja karyawan.

\section{c. Pengaruh Rekan Kerja Terhadap Kepuasan Kerja Karyawan}

Menurut Kamus Besar Bahasa Indonesia Suharso dan Retnoningsih 2005:79, rekan kerja adalah orang yang mempunyai hubungan timbal balik dalam satu tempat kerja. Rekan kerja diukur melalui indikator sebagai berikut (Sudriamunawar: 2006):

a. Kompetisi yang sehat merupakan persaingan diantara sesama rekan kerja untuk mencapai jabatan yang tertinggi.

b. Karyawan saling menghormati merupakan sikap dan tindakan karyawan dalam menghargai sesaa rekan kerja.

c. Karyawan saling bekerja sama dalam menyelesaikan masalah merupakan tindakan tindakan karyawan untuk menyelesaikan masalah yang dirasa cukup rumit, baik yang terjadi pada seorang karyawan maupun seluruh karyawan.

Suasana kekeluragaan yang ada merupakan kondisi yang terjadi pada lingkungan perusahaan agar suasana kekeluargaan selalu terjadi dengan harmonis, maka masing masing pihak harus saling menghormati dan 
mencari suatu cara agar hubungan diantara rekan kerja tetap harmonis, baik saat bekerja maupun di luar pekerjaan (Nitisemito, 1992)

Rekan kerja merupakan lingkungan kerja terdekat yang akan mepengaruhi situasi kerja dan berpengaruh pada motivasi dan prestasi. Rekan sekerja yang menunjukkan sikap bersahabat dan mendukung dapat memberikan kepuasan. Kenyataannya kebanyakan orang, kerja selain untuk mencari uang juga memenuhi kebutuhan interaksi sosial. Oleh sebab itu tidaklah mengejutkan bila mempunyai rekan sekerja yang baik dan ramah akan meningkatkankepuasan kerja.

Siagian (2002:121-122) menegaskan manusia berkarya tidak hanya sekedar mencari nafkah, meskipun hal itu tetap penting, melainkan sebagai wahana untuk menggangkat harkat dan martabat, berarti untuk memuaskan kebutuhan harga diri, antara lain melalui perolehan pengakuan dan penghargaan dari orang lain. Seperti atasan, rekan kerja dan bawahan. Kelly dalam Jackson (2003:80) mengungkapkan hasil penelitiannya pada sebuah bank, rekan kerja mempunyai sumbangan terbesar terhadap kepuasan kerja karyawan yang kemudiaan diikuti oleh variabel yain yaitu kondisi kerja.

\section{Metode Penelitian (Methodology)}

\section{a. Metode dan Variabel Penelitian}

Penelitian ini berusaha untuk menjawab rumusan masalah yang diajukan dan menguji hipotesis yang ada, maka metode yang digunakan pada penelitian ini adalah metode penelitian kuantiantif. Pada dasarnya tujuan penelitian ini nantinya yaitu untuk menjawab secara deskriptif rumusan masalah. Penelitian deskriptif merupakan penelitian yang bertujuan untuk memperoleh deskripsi tentang gaji, promosi jabatan dan rekan kerja serta kepuasan kerja, Sifat penelitian verifikatif adalah untuk menguji kebenaran suatu hipotesis yang dilaksanakan melalui pengumpulan data di lapangan, dimana dalam penelitian ini akan diuji pengaruh gaji, promosi jabatan dan rekan kerja terhadap kepuasan kerja Karyawan di PT Bank Rakyat Indonesia (Persero) Tbk Kantor Cabang Bireuen.

Adapun variabel, dimensi dan indikator pengukurnya di definisikan berikut ini.

Tabel 1. Operasional Variabel Penelitian

\begin{tabular}{|c|c|c|}
\hline Variabel & Defenisi Konsep & Indikator \\
\hline $\begin{array}{l}\text { Gaji } \\
\text { (X1) }\end{array}$ & $\begin{array}{l}\text { Gaji adalah balas jasa dalam bentuk uang } \\
\text { yang diterima karyawan sebagai konsekuensi } \\
\text { dari statusnya sebagai pegawai yg } \\
\text { memberikan konstribusi dalam mencapai } \\
\text { tujuan perusahaan. } \\
\text { Dengan dimensi; Tingkat gaji, (pay level), } \\
\text { Kompensasi (benefit), kenaikan gaji (pay } \\
\text { raise), sturktur atau pengelolaan gaji (pay } \\
\text { structure and administration). } \\
\text { Rivai (2005) dalam Kadarisman (2012:316) }\end{array}$ & $\begin{array}{l}\text { - Besar gaji } \\
\text { - Keadilan gaji } \\
\text { - Kesesuaian gaji } \\
\text { - Keuntungan } \\
\text { - Manfaat } \\
\text { - Besar Kenaikan upah } \\
\text { - Nilai besar kecilnya upah atau gaji } \\
\text { berdasarkan tingkat atau kedudukannya } \\
\text { dalan suatu perusahaan }\end{array}$ \\
\hline $\begin{array}{l}\text { Promosi Jabatan } \\
\text { (X2) }\end{array}$ & $\begin{array}{l}\text { Promosi berarti perpindahan dari suatu } \\
\text { jabatan ke jabatan yang lain yang mempunyai } \\
\text { status dan tanggung jawab yang lebih tinggi. } \\
\text { Hal ini berarti bahwa kompensasi } \\
\text { (penerimaan upah/gaji dan sebagainya) } \\
\text { menjadi lebih tinggi dibanding dengan jabatan } \\
\text { lama. } \\
\text { Dengan dimensinya adalah Peningkatan } \\
\text { tanggung jawab pekerjaan, dan } \\
\text { Pengembangan peningkatan tugas. } \\
\text { Samsudin (dalam Kadarisman, 2012) }\end{array}$ & $\begin{array}{l}\text { - penilaian pelaksanaan pekerjaan, } \\
\text { - Pengingkatan konsistensi pekerjaan, } \\
\text { - kemungkinan pengembangan, } \\
\text { - keahlian yang lebih. } \\
\text { - Pengalaman } \\
\text { - pengetahuan yang memadai, } \\
\text { - status pendidikan } \\
\text { - dapat dipercaya. }\end{array}$ \\
\hline Rekan Kerja (X3) & $\begin{array}{l}\text { Rekan kerja adalah orang yang mempunyai } \\
\text { hubungan timbal balik dalam satu tempat } \\
\text { kerja } \\
\text { Dimensinya; Kompetisi, Saling Menghormati, } \\
\text { Kerja sama, dan Kekeluargaan } \\
\text { Suharso dan Retnoningsih (2005:79) }\end{array}$ & $\begin{array}{l}\text { - Kompetisi yang sehat. } \\
\text { - Karyawan saling menghormati dan } \\
\text { menghargai sesama rekan kerja. } \\
\text { - Saling bekerja sama dalam menyelesaikan } \\
\text { masalah. } \\
\text { - Suasana kekeluragaan yang terjadi pada } \\
\text { lingkungan perusahaan (Nitisemito, 1992) }\end{array}$ \\
\hline $\begin{array}{l}\text { Kepuasan Kerja } \\
\text { (Y) }\end{array}$ & $\begin{array}{l}\text { Kepuasan Kerja adalah keadaan emosional } \\
\text { yang merupakan hasl dari evaluasi pengalama }\end{array}$ & $\begin{array}{l}\text { - Pekerjaan yang menarik } \\
\text { - Pekerjaan yang menantang }\end{array}$ \\
\hline
\end{tabular}




\begin{tabular}{|l|l|l|}
\hline & kerja seseorang. \\
Dimensinya; Pekerjaan itu sendiri, Gaji, & $\begin{array}{l}\bullet \text { pekerjaan yang tidak membosankan, } \\
\text { Promosi Jabatan, Supervisi, dan Kondisi } \\
\text { Kerja }\end{array}$ & $\begin{array}{l}\bullet \text { pekerjaan yang dapat memberikan status. } \\
\text { Luthan }(2006: 243)\end{array}$ \\
& $\begin{array}{l}\text { Besar Gaji, Keadilan, Kesesuain Gaji } \\
\text { Promosi } \\
\end{array}$ \\
& $\begin{array}{l}\text { - Faktor Atasan } \\
\bullet \text { Instruksi } \\
\bullet \text { Lingkungan, Suasana dan Fasilitas Kerja }\end{array}$ \\
\hline
\end{tabular}

\section{b. Populasi dan Sampel Penelitian}

Populasi penelitian adalah seluruh karyawan BRI Cabang Bireuen yaitu sebanyak 182 orang karyawan, dengan rincian yang berstatus sebagai karyawan tetap sebanyak 82 orang, karyawan kontrak 42 orang, dan outsourching 58 orang. Dari jumlah tersebut diambil sampel sebagian karyawan terpilih.

Teknik sampling yang digunakan pada penelitian ini sesuai dengan pendapat Sugiyono (2010:2017) perihal Teknik Sampling yaitu Probality Sampling yang berarti teknik sampling yang memberikan peluang yang sama bagi setiap unsure (anggota) populasi untuk dipilih menjadi sampel.

Penentuan jumlah sampel dari populasi menggunakan rumus yang dikembangkan oleh slovin untuk tingkat kesalahan 5\% (Sugiyono, 2011) dapat dihitung dengan menggunakan rumus sebagai berikut:

$$
\boldsymbol{s}=\frac{N}{d^{2} \cdot N+1} \quad \begin{aligned}
& \text { Keterangan: } \\
& \mathrm{S}=\text { Jumlah sampel } \\
& \mathrm{N}=\text { Jumlah populasi yaitu } \\
& \mathrm{d}=\text { Presisi yang ditetapkan }(0.05)
\end{aligned}
$$

Sehingga yang menjadi sampel pada penelitian ini nantinya adalah sebanyak 125 orang karyawan, baik dengan karyawan yang berstatus karyawan tetap, karyawan kontrak, karyawan outsourching yang ada di bawah Kantor Cabang BRI Bireuen.

\section{c. Alat Analisis}

Berdasarkan paradigma dan hipotesis penelitian yang telah disajikan sebelumnya, maka metode analisis data yang digunakan adalah Multiple Regresion (Analisis Regresi Berganda) dan menggunakan metode penelitian deskriptif kuantitatif. Teknik analisis data yang digunakan adalah analisis regresi ganda dengan SPSS 17. Dengan model regresinya adalah: $\mathrm{Y}=a+\mathrm{b} 1 \mathrm{X} 1+\mathrm{b} 2 \mathrm{X} 2+\mathrm{b} 3 \mathrm{X} 3+e$

Variabel bebas (X) dalam penelitian ini adalah Gaji, Promosi Jabatan dan rekan kerja, Sedangkan variabel terikatnya (Y) adalah Kepuasan karyawan.

Jenis pendekatan kuantitatif, dimana pendekatan kuantitatif merupakan penelitian yang berbentuk angka untuk menguji suatu hipotesis. Penelitian kuantitatif adalah metode penelitian yang berlandaskan pada filsafat positivisme, digunakan untuk meneliti pada populasi atau sampel tertentu, pengumpulan data menggunakan instrumen penelitian, analisis data bersifat kuantitatif atau statistik, dengan tujuan untuk menguji hipotesis yang telah ditetapkan.

Kuesioner penelitian dirancang dengan menggunakan skala Likert. Skala Likert terdiri dari sejumlah pernyataan yang semuanya menunjukkan sikap terhadap suatu objek tertentu yang akan diukur. Untuk setiap pernyataan, disediakan sejumlah alternatif tanggapan yang berjenjang atau bertingkat, yakni sangat setuju, setuju, kurang setuju, tidak setuju dan sangat tidak setuju. Oleh karenanya, sebelum dilakukan analisis data dengan pendekatan regresi, data dikonversi terlebih dahulu sehingga memiliki skala interval dengan metode sussesive interval.

Untuk dapat menggunakan alat analisis ini, dipastikan data memiliki skala ukur minimal interval. Juga syarat statistik regresi dan analisis jalur, terpenuhinya semua asumsi klasik, yakni normalitas, heterosidasitas, multikolinieritas.

\section{Hasil dan Pembahasan (Results and Discussion)}

\section{a. Karakteristik Responden}

Responden dalam penelitian ini berjumlah 125 karyawan PT Bank Rakyat Indonesia (Persero) Cabang Bireuen, dengan karakteristik responden adalah: 
Tabel 2. Karakteristik Responden Berdasarkan Jenis Kelamin

\begin{tabular}{|c|c|c|}
\hline Karateristik & Jumlah (orang) & Persentase (\%) \\
\hline Kelamin : Laki-laki & 66 & 53,8 \\
\hline Perempuan & 59 & 47,2 \\
\hline Usia 30 Thn & 28 & 22,4 \\
\hline 30-40 Thn & 72 & 57,6 \\
\hline$>$ 40 Thn & 25 & 20,0 \\
\hline Jabatan/Unit: Marketing & 37 & 29,6 \\
\hline Operasional & 34 & 27,2 \\
\hline Penunjang Operasional & 34 & 27,2 \\
\hline Penunjang Bisnis & 20 & 16,0 \\
\hline SLTA & 16 & 12,8 \\
\hline Sarjana & 109 & 87,2 \\
\hline Mendidikan: & 22 & 17,6 \\
\hline 5 - 10 Tahun & 63 & 50,4 \\
\hline$>$ 10 Tahun & 40 & 32,0 \\
\hline Kanan & 78 & 62,4 \\
\hline Outsourcing & 29 & 23,2 \\
\hline Total & 18 & 14,4 \\
\hline
\end{tabular}

Sumber : Penelitian di PT Bank Rakyat Indonesia (Persero) Tbk. Cabang Bireuen, 2020

\section{b. Hasil analisis Deskriptif}

Tabel 3. Hasil Deskriptif Statistik Pada Variabel Penelitian

\begin{tabular}{|c|l|c|c|c|c|}
\hline No & \multicolumn{1}{|c|}{ Variabel } & Skor Pnelitian & Skor Ideal & Persen Pencapaian & Kategori \\
\hline 1 & Kepuasan Gaji & 5804 & 6875 & $84,42 \%$ & Baik \\
\hline 2 & Kepuasan Promosi & 6795 & 8125 & $83,63 \%$ & Baik \\
\hline 3 & Kepuasan Rekan kerja & 6233 & 7500 & $83,11 \%$ & Baik \\
\hline 4 & Kepuasan kerja & 4650 & 5625 & $82,67 \%$ & Baik \\
\hline
\end{tabular}

Variabel gaji diukur berdasarkan dimensi tingkat gaji (pay level), Kompensasi (benefit), kenaikan gaji (pay raise), dan Struktur atau pengelolaan gaji (pay structure and administration). Hasil persepsi karyawan, tingkat pencapaian dalam kepuasan gaji mencapai $84,42 \%$. Dalam hal ini berarti faktor gaji sudah termasuk baik.

Variabel promosi diukur berdasarkan dimensi Peningkatan tanggung jawab pekerjaan, dan Pengembangan peningkatan tugas. Hasilnya bahwa tingkat pencapaian dalam kepuasan promosi mencapai 83,63\%. Dalam hal ini berarti faktor promosi terhadap karier karyawan sudah termasuk baik.

Variabel Rekan kerja diukur berdasarkan dimensi Kompetisi, Saling menghormati, Kerjasama dan kekeluargaan. Diperoleh, tingkat pencapaian dalam kepuasan rekan kerjamencapai 83,11\%. Dalam hal ini berarti faktor rekan kerja sudah termasuk baik.

Variabel Kepuasan kerja diukur berdasarkan dimensi Pekerjaan itu sendiri, Gaji, Promosi Jabatan, Supervisi, dan Kondisi kerja. Hasil pengukuran bahwa tingkat pencapaian dalam kepuasan kerja mencapai $82,67 \%$. Dalam hal ini berarti kepuasan kerja karyawan sudah termasuk baik.

\section{c. Hasil Analisis Regresi}

Dalam penelitian ini model analisis rehresi, yakni menganalisis masing-masing variabel bebas terhadap variabel tak bebas, yang disebut uji secara parsial, yakni pengaruh gaji $\left(\mathrm{X}_{1}\right)$, promosi $\left(\mathrm{X}_{2}\right)$ dan Rekan kerja $\left(\mathrm{X}_{3}\right)$ terhadap Kepuasan kerja Karyawan $(\mathrm{Y})$. Adapun pembuktian masing-masing koefisien regresi melalui hipotesis secara parsial, dapat dilihat pada tabel berikut ini:

Tabel 4. Pengujian Parsial variabel Bebas

\begin{tabular}{|l|l|c|c|c|c|c|}
\hline \multirow{2}{*}{ Model } & \multicolumn{2}{|c|}{ Unstandardized Coefficients } & Standardized Coefficients & & \\
\cline { 2 - 7 } & $\mathrm{B}$ & Std. Error & Beta & $\mathrm{t}$ & Sig. \\
\hline \multirow{3}{*}{1} & (Constant) & 2.010 & 1.678 & & 1.198 & .233 \\
\cline { 2 - 7 } & Gaji & 0.253 & 0.065 & 0.287 & 3.910 & 0.000 \\
\cline { 2 - 7 } & Promosi & 0.034 & 0.051 & 0.050 & 0.656 & 0.513 \\
\cline { 2 - 7 } & Rekan Kerja & 0.445 & 0.051 & 0.597 & 8.726 & 0.000 \\
\hline
\end{tabular}

Sumber : Hasil penelitian, 2010, olahan dengan Spss, 
Berdasarkan data tabel 4. diatas, maka dilakukan uji hipotesis berikut:

\section{Hipotesis 1}

Ho: $\rho_{\mathrm{yx}} \leq 0$ : Faktor gaji $\left(\mathrm{X}_{1}\right)$ tidak berpengaruh terhadap Kepuasan kerja $(\mathrm{Y})$

$\mathrm{H}_{1}: \rho_{\mathrm{yx} 1}>0$ : Faktor gaji $\left(\mathrm{X}_{1}\right)$ berpengaruh terhadap Kepuasan kerja $(\mathrm{Y})$

Kriteria pengujian adalah total Ho jika hasil $\mathrm{t}_{\text {hitung }}$ dinyatkan signifikans dibawah taraf uji $5 \%$ atauu sig $=$ 0,05 . Dari tabel diatas, Hipotesis ini menyatakan ada pengaruh faktor gaji terhadap Kepuasan kerja, karena nilai sig uji $=0,000$.

\section{Hipotesis 2}

Ho: $\rho_{\mathrm{yx} 2} \leq 0$ : Faktor Promosi $\left(\mathrm{X}_{2}\right)$ tidak berpengaruh terhadap Kepuasan kerja $(\mathrm{Y})$

$\mathrm{H}_{1}: \rho_{\mathrm{yx} 2}>0$ : Faktor Promosi $\left(\mathrm{X}_{2}\right)$ berpengaruh terhadap Kepuasan kerja $(\mathrm{Y})$

Hasil perhitungan uji individu menunjukkan harga $t_{\text {hitung }}$ sebesar 0,656. Dengan nilai sig $=0,513$ atau 51,3\% Sehingga Ho diterima artinya faktor promosi tidak berpengaruh terhadap Kepuasan kerja

\section{Hipotesis 3}

Ho: $\rho_{\mathrm{yx} 3} \leq 0$ : Faktor Rekan kerja $\left(\mathrm{X}_{3}\right)$ tidak berpengaruh terhadap Kepuasan kerja

$\mathrm{H}_{1}: \rho_{\mathrm{yx} 3}>0$ : Faktor Rekan kerja $\left(\mathrm{X}_{3}\right)$ berpengaruh terhadap Kepuasan kerja $(\mathrm{Y})$

Hasil perhitungan uji individu menunjukkan harga $\mathrm{t}_{\text {hitung }}$ sebesar 8,726. Dengan nilai sig $=0,000$ atau $0,0 \%$ Sehingga Ho ditolak, dan $\mathrm{H} 1$ terima artinya faktor Rekan kerja berpengaruh terhadap Kepuasan kerja.

\section{d. Pembahasan}

\section{1) Pengaruh gaji terhadap kepuasan kerja karyawan}

Hasil penelitian mendukung hipotesis pertama bahwa variabel gaji (X1), berpengaruh positif secara parsial terhadap kepuasan kerja karyawan BRI Cabang Bireuen, hal ini ditunjukkan dengan nilai koefisien regresi $\mathrm{X} 1$ adalah sebesar 0,253 yang menyatakan bahwa setiap kenaikan gaji sebesar 10\% akan meningkatkan kepuasan kerja karyawan BRI Cabang Bireuen sebesar 2,53\%.

Hasil penelitian yang mendukung hipotesis tersebut membenarkan pendapat J.Dubunsky, Masaaki Kotabe dan Chae Un Lim dalam Farida (2001), bahwa aturan main pembayaran kompensasi, tinggi rendahnya tingkat kompensasi dan kebijakan atas jabatan tertentu berkorelasi positif terhadap kepuasan kerja.

Perihal bahwa gaji berpengaruh terhadap kepuasan kerja ini juga sesuai dengan peranan gaji. Menurut Peorwono (Samsuddin, Sadili, 2009), dimana dari dua aspek yang menjadi peranan gaji, jika dilihat dari aspek penerima gaji disampaikan oleh beliau bahwa Gaji merupakan penghasilan yang diterima oleh seseorang dan digunakan untuk memenguhi kebutuhannya. Gaji bukanlah merupakan satu satunya motivasi karyawan dalam berprestasi, tetapi gaji merupakan salah satu motivasi penting yang ikut mendorong karyawan untuk berprestasi, sehingga tinggi rendahnya gaji yang diberikan akan mempengaruhi kinerja dan kesetiaan karyawan.

\section{2) Pengaruh promosi jabatan terhadap kepuasan kerja karyawan}

Hasil penelitian menunjukkan bahwa ternyata promosi jabatan tidak mempengaruhi kepuasan kerja karyawan BRI Cabang Bireuen, hal ini ditunjukkan dengan nilai sig untuk variabel X2 (promosi jabatan) terhadap Y (kepuasan kerja) 0,513 atau 51,3\%, artinya diatas taraf ui 5\%, yang sekaligus dalam kasus yang diteliti membuktikan promosi jabatan tidak berpengaruh terhadap kepuasan kerja karyawan.

Penelitian ini ditolerir juga dari penelitian Maris Tri Wardani, Ign.Wagimin, Anton Subarno dengan judul Analisis Faktor-faktor kepuasan kerja pada Karyawan PT Bank Tabungan Negara Kantor Cabang Solo menyatakan bahwa tidak semua variabel berpengaruh secara parsial terhadap kepuasan kerja karyawan dan Pada penelitian yang dilakukan di BRI Cabang Bireuen, variabel yang dimaksud adalah promosi jabatan.

Selanjutnya penulis mencoba mendalami lagi pengertian dari promosi jabatan yang disampaikan oleh para ahli seperti Samsudin (dalam Kadarisman, 2012: 126-127) promosi berarti perpindahan dari suatu jabatan ke jabatan yang lain yang mempunyai status dan tanggung jawab yang lebih tinggi. Atau pengertian promosi jabatan yang disampaikan oleh Siswanto (2005: 258) menyatakan bahwa "Promosi dapat diartikan sebagai proses perubahan dari satu pekerjaan ke pekerjaan lain dalam hierarki wewenang dan tanggung jawab yang lebih tinggi daripada wewenang dan tanggun jawab yang telah diberikan keoada tenaga kerja pada waktu sebelumnya".

Dan dari pengertian promosi jabatan di atas, hampir semua para ahli sependapat bahwa promosi jabatan merupakan perpindahan karyawan dari satu jabatan ke jabatan lain yang lebih tinggi, dimana diikuti oleh tugas dan tanggung jawab yang lebih berat, dan dikarenakan karena dengan mendapat promosi jabatan maka 
akan bertambah tugas dan tanggung jawab, sehingga tidak semua orang tertarik untuk mendapat promosi jabatan, karena biasanya orang merasa tidak suka jika harus menambah tugas dan tanggung jawab meskipun perubahan tersebut juga diikuti oleh perubahan kompensasi dan lainnya.

Tetty Juliaty berpendapat penyebab promosi jabatan tidak lagi menggiurkan, yakni tidak nyaman, tekanan, gaji tak sesuai, tanggung jawab dan beban kerja tak sesuai, intervensi pihak lain, lokasi dan politik kantor, sehingga tidak jarang karyawan saat ini kurang tertarik untuk mendapat promosi jabatan

Dan untuk BRI Cabang Bireuen sendiri, lokasi menjadi faktor utama promosi jabatan kurang diminati, mereka lebih memilih tetap di daerah asal dan bisa berkumpul bersama keluarga dibandingkan mendapat promosi jabatan dan harus berpindah pindah tempat ke unit kerja lain sehingga jauh dari keluarga, Hal tersebut dimungkinkan yang menjadi penyebab promosi jabatan tidak menjadi faktor kepuasan kerja karyawan BRI Cabang Bireuen.

\section{3) Pengaruh Rekan Kerja terhadap kepuasan kerja karyawan}

Hasil penelitian mendukung hipotesis ketiga yaitu Rekan Kerja berpengaruh terhadap kepuasan kerja karyawan BRI Cabang Bireuen jika dihitung secara parsial dengan nilai koefisien regresi sebesar 0,445 maknanya bahwa bahwa setiap adanya dukungan dari rekan kerja sebanyak satu satuan akan meningkatkan kepuasan kerja sebanyak 0,455 satuan.

Hasil penelitian yang mendukung hipotesis ini juga berarti sependapat dengan penelitian yang pernah dilakukan oleh Kelly dalam Jackson (2003:80) mengungkapkan hasil penelitiannya pada sebuah bank, rekan kerja mempunyai sumbangan terbesar terhadap kepuasan kerja karyawan yang kemudiaan diikuti oleh variabel yain yaitu kondisi kerja.

Sehingga benar seperti yang telah disampaikan oleh Siagian (2002:121-122) bahwa manusia berkarya tidak hanya sekedar mencari nafkah, meskipun hal itu tetap penting, melainkan sebagai wahana untuk menggangkat harkat dan martabat, berarti untuk memuaskan kebutuhan harga diri, antara lain melalui perolehan pengakuan dan penghargaan dari orang lain. Seperti atasan, rekan kerja dan bawahan.

Rekan kerja merupakan lingkungan kerja terdekat yang akan mepengaruhi situasi kerja dan berpengaruh pada motivasi dan prestasi. Rekan sekerja yang menunjukkan sikap bersahabat dan mendukung dapat memberikan kepuasan. Kenyataannya kebanyakan orang, kerja selain untuk mencari uang juga memenuhi kebutuhan interaksi sosial. Oleh sebab itu tidaklah mengejutkan bila mempunyai rekan sekerja yang baik dan ramah akan meningkatkankepuasan kerja.

\section{4) Pengaruh gaji, promosi jabatan, dan rekan kerja terhadap kepuasan kerja karyawan.}

Hasil penelitian menunjukan bahwa Gaji, Promosi Jabatan dan rekan kerja secara simultan berpengaruh terhadap kepuasan kerja karyawan BRI Cabang Bireuen. Hal ini dibuktikan dari uji-F. Dan didukung dari nilai koefisien determinasi yakni 0,731 atau sebesar 73,1\% yang bararti bahwa besarnya pengaruh gaji, promosi jabatan dan rekan kerja secara simultan terhadap kepuasan kerja karyawan BRI Cabang Bireuen adalah sebesar 73,1\%, selebihnya adalah faktor lain yang tidak diteliti.

Penelitian ini sesuai dengan penelitian yang dilakukan oleh Tri Wardani, Ign.Wagimin, Anton Subarno dengan judul Analisis Faktor-faktor kepuasan kerja pada Karyawan PT Bank Tabungan Negara Kantor Cabang Solo yang menyatakan bahwa Terdapat pengaruh yang signifikan antara faktor gaji, pekerjaan, promosi jabatan, supervisor dan rekan sekerja secara simultan terhadap kepuasan kerja dengan kompensasi finansial sebagai variabel moderator pada karyawan PT Bank Tabungan Negara Kantor Cabang Solo.

Sehingga jika dilihat secara simultan dapat disampaikan bahwa hasil penelitian ini sejalan dengan grand teori pada penelitian ini yaitu pendapat yang dikemukakan oleh Luthans (2006:24:3) yang menjelaskan bahwa Dimensi serta indikator kepuasan kerja adalah Pekerjaan itu sendiri, Gaji, Promosi, Supervisi, Rekan Kerja, Kondisi Kerja.

\section{Simpulan (Conclusion)}

Dari hasil penelitian, pengumpulan data, observasi dan pengolahan data yang penulis lakukan, diperoleh simpulan penelitian, yakni:

1) Hasil Penelitian menunjukkan dari tiga variabel independent yaitu gaji, promosi jabatan dan rekan kerja, diperoleh hasil bahwa gaji dan rekan kerja secara parsial berpengaruh terhadap kepuasan kerja karyawan dengan nilai koefisien regresi gaji (X1) adalah sebesar 0.288 dan rekan kerja (X3) sebesar 0.451 sedangkan Promosi Jabatan (X2) tidak berpengaruh dengan nilai koefisien regresi sebesar 0.63 
2) Secara simultan, gaji, promosi jabatan, rekan kerja berpengaruh terhadap kepuasan kerja karyawan BRI Cabang Bireuen nilai $\mathbf{R}^{2}=0,754$ atau sebesar $75,4 \%$ selebihnya dipengaruhi oleh faktor lain yang tidak dibahas.

\section{DAFTAR PUSTAKA (References)}

1) Adam Ibrahim Indra Wijaya,. 2000, Perilaku Organisasi. Jakarta: Sinar Baru. Algesindo.

2) Alex S. Nitisemito, 1992, Manajemen dan Sumber Daya Manusia, BPFE UGM,. Yogyakarta.

3) Andini, Rita. 2006. Analisis Pengaruh Kepuasan Gaji, Kepuasan Kerja, Komitmen Organisasional pada Turnover Intention (Studi Kasus pada Rumah Sakit Roemani Muhammadiyah Semarang). Majalah Ilmiah Universitas Pandanaran, 8(16), h: 1-10

4) Haryono Sudriamunawar. 2006. Kepemimpinan, Peran Serta dan Produktivitas. Cetakan I. Bandung: Mandar Maju.

5) Kadarisman. 2012. Manajemen Pengembangan Sumber Daya Manusia. Jakarta: Raja Grafindo Persada

6) Kosteas, Vasilios D, 2009. Job Satisfaction and Promotions. Journal of Cleveland. State University, pp: 1-35.

7) Luthans, Fred. 2006. Organizational Behavior. New York: McGraw Hill.

8) Moekijat, 2003, Manajemen Kekaryawanan Dan Hubungan Dalam. Perusahaan, Edisi Ketiga, Alumni Bandung.

9) Naveed et al. 2011. Effect of Transformational Leadership on Employees' Job Satisfaction and Organizational Commitment in Banking Sector of Lahore (Pakistan). International Journal of Business and Social Science, Vol. 2 (18), pp.:261-267

10) Retnoningsih dan Suharso, 2006. Kamus Besar Bahasa Indonesia, Semarang: CV. Widya Karya

11) Robbins, Stephen P. 2001. Perilaku Organisasi: Konsep, Kontroversi, Aplikasi, Jilid. 1, Edisi 8, Prenhallindo, Jakarta.

12) Sadili, Samsudin, 2009, Manajemen Sumber Daya Manusia. Bandung : CV. Pustaka Setia

13) Sastrohadiwiryo, B.S. 2005. Manajemen Tenaga Kerja Indonesia Pendekatan. Administratif dan Operasional. Jakarta: PT. Bumi Aksara.

14) Schuler, R.S. dan Jackson, S.E. 2003. Manajemen Sumber Daya Manusia;. Menghadapi Abad Ke- 21. Edisi Ke-Enam. Jakarta: Erlangga.

15) Siagian Sondang P., 2002. Kiat Meningkatkan Produktivitas Kerja, Cetakan-1, PT. Rineka Cipta

16) Siswanto. 2005. Manajemen Tenaga Kerja Indonesia Pendekatan. Administrarif dan Operasional. Jakarta: Bumi Aksara

17) Sugiyono. 2011. Metode Penelitian Kuantitatif, Kualitatif dan R\&D. Bandung: Afabeta

18) Suwandi, dan Nur Indriantoro. 2009, Pengujian Model Turnover Pasewark dan Strawser: Studi Empiris pada Lingkungan Akuntansi Publik, Jurnal Riset Akuntansi Indonesia, No.2,halaman 173-195

19) Tri Wardani, Ign.Wagimin, Anton Subarno, Analisis Faktor-faktor kepuasan kerja pada Karyawan PT Bank Tabungan Negara Kantor Cabang Solo, https://media.neliti.com/media/publications/117438-IDanalisis-faktor-faktor-kepuasan-kerja-pa.pdf 